\title{
Forest Change Monitoring and Environmental Impact in Gunung Palung National Park, West Kalimantan, Indonesia
}

\author{
Nurul Ihsan Fawzi ${ }^{1,}{ }^{*}$, Angela Meike Indrayani ${ }^{1}$, Keva DeKay ${ }^{2}$, \\ ${ }^{1}$ Alam Sehat Lestari, Sukadana, West Kalimantan, Indonesia 78852 \\ Email: nurul.ihsan.f@mail.ugm.ac.id \\ ${ }^{2}$ School of Public Health, UC Berkeley, Berkeley, CA 94720-7360
}

\begin{abstract}
Deforestation and forest degradation should be monitored regularly in order to plan and implement early conservation interventions. Monitoring forest change is important in Gunung Palung National Park because the park is a habitat for 2,500 orangutans. The park has experienced severe forest loss caused by anthropogenic activities and forest fires. We measured forest cover change in the protected area using 12 multi-temporal Landsat series images path/row 121/61. From the beginning of monitoring, the park has already lost 10,864 Ha or $10 \%$ of its oldgrowth forest and retained $90 \%$ or 97,148 Ha. El Niño events in 1997 and 2015 caused the park to lose 30\% and $1.1 \%$ of its old-growth forest, respectively. The old-growth forest was lost due to a combination of drought, wildfire, and individual loggers and timber companies illegally expanding their operations in the park. The implication for the environment is the change of forest to secondary forest affects biological diversity and drives invasive species Bellucia pentamera Naudin to occupy the canopy gap in the park. The water retention in the park also changes and will cause a decrease of water availability, and specifically cause drought in the dry season. Between 2015 and 2018 , no deforestation was detected with 30-meter resolution Landsat satellites. In the future, we must think about reforestation because reforestation also has a positive impact on improving biodiversity.
\end{abstract}

Keyword: Gunung Palung, forest monitoring, remote sensing, environmental impact from deforestation

Citation: Fawzi, N. I., Indrayani, A. M., dan DeKay, K. (2019). Forest Change Monitoring and Environmental Impact in Gunung Palung National Park, West Kalimantan, Indonesia. Jurnal Ilmu Lingkungan, 17(2),197-204, doi:10.14710/jil.17.2.197-204

\section{Introduction}

Tropical deforestation and degradation impact biodiversity loss and carbon emission (Barlow et al., 2016; Giam, 2017). The $\mathrm{CO}_{2}$ emissions from global deforestation contribute $6-17 \%$ of global emissions, around 1 peta-gram Carbon per year (Baccini et al., 2012). In Kalimantan (Indonesian Borneo), 14,4 Million hectares of forest were deforested between 1973 - 2015 (Gaveau et al., 2016). This tropical deforestation also contributes to an increase 8.6 petagram of $\mathrm{CO}_{2}$ released to atmosphere (Rosa et al., 2016). Oil palm plantations (Elaeis guineensis Jacq.) have becoming the major cause of deforestation in Kalimantan (Gaveau et al., 2019; Tsujino et al., 2016). This mirrors global deforestation, which is mostly caused by commercial agriculture activities and subsistence farming (Curtis et al., 2018).

Changing the forest into a protected area did not dissociate the forest from deforestation. Gunung Palung National Park is a part of 15\% forested area in Indonesia which is protected, but the park has already lost its forest from deforestation (Hiller et al., 2004). El Niño's wildfire and export oriented logging activity caused the park to lose $38 \%$ of its forest
(Curran et al., 2004; Tsujino et al., 2016). The rate of deforestation between $1994-2002$ is $9.5 \%$ per year but has been decreasing gradually since the government developed improved forestry policies (Tacconi et al., 2019).

Deforestation and forest degradation should be monitored regularly in order to plan and implement early conservation interventions. Conservation relies on monitoring data to support policy decisions and to evaluate the effectiveness of methods (Rasmussen and Jepsen, 2018). It is essential to identify timely monitoring information. Monitoring forest change is important in Gunung Palung National Park because the park is a habitat for 2,500 orangutans (Johnson et al., 2005).

Forest monitoring at Gunung Palung National Park has been discussed in several papers but each has limitations. The first monitoring was conducted by Zamzani et al. (2009), which found that $18.7 \%$ of the forest has been deforested at a rate of $1.6 \%$ per year between 1992-2004. The data used was Landsat TM acquired at 1992, Landsat $\mathrm{ETM}^{+}$acquired at 199, and SPOT 5 image acquired at 2004. Zamzani et al. (2009) only showed classification tables and didn't produce any maps. Tricahyono et al. (2016) also 
used Landsat images to analyze forest changes in the park. The data used was acquired in 2005 and 2012. They found that only 1,122.21 Ha of the national park had been deforested. This research didn't explain the deforestation during the 1990s. The most recent research that explains agents and drivers of deforestation was conducted by Yoshikura et al. (2016). Yoshikura et al. (2016) performed a land cover analysis in 2013, but there were many missclassifications, where only some garden areas were classified as secondary forest because they had the same canopy as the forest. Although the cause of deforestation had was explained in the paper, the data was the limitated by one-time measurements of the forest. The latest research about forest monitoring was conducted by Fawzi et al. (2018), who measured annual deforestation rate in Gunung Palung National Park. This research had some limitations because it didn't explain the El Niño events of 2015 or the second-growth secondary forest. Some areas from the degraded forest regenerated into a secondary forest. The previous research didn't explain the impact of forest changes; rather, they only identfied the cause of deforestation. Two of the studies also failed to explain the process of ecosystem change in the park because of a lack of long-term monitoring.

Forest monitoring usually uses in situ data collection, but it can be expensive if it is done in a large conservation area and it will be much more difficult to collect data in remote areas. Using remote sensing techniques is the best option because it is time- and cost-effective and can capture long-term changes (Grecchi et al., 2017; Langner et al., 2012; Wang et al., 2010). Part of forest monitoring is assessing environmental impact from change in the forest.

The aim of this research is to monitor forest change in Gunung Palung National Park and to discuss its implication for the environment. In this article, we analyze forest change from 1989 to 2018 and discuss the environmental impact from the changes.

\section{Method}

\subsection{Study area}

Gunung Palung National Park has been protected since 1937 . It is home to many endangered and critically endangered wildlife species. Orangutan (Pongo pygmaeus ssp. wurmbii) is a critically endangered species and should be an international concern (Ancrenaz et al., 2016). The endangered and vulnerable species that have become the key species of the park are proboscis monkeys (Nasalis larvatus), sun bears (Helarctos malayanus), sunda clouded leopard (Neofelis diardi) and rhinoceros hornbills (Buceros rhinoceros) (BirdLife International, 2018; Hearn et al., 2015; Meijaard et al., 2008; Scotson et al., 2017).
Located within two regencies, North Kayong and Ketapang, West Kalimantan (103' - 1022' S, $109^{\circ} 54^{\prime}-110^{\circ} 28^{\prime}$ E, Figure 1), the park expanded its area from $300 \mathrm{~km}^{2}$ to $1,080 \mathrm{~km}^{2}$. The purpose of this park is to conserve many types of ecosystems, such as montane forest, peat forest, mangrove forest and tropical heath forest. Around 60,000 people live around the park and their livelihoods depend on the forest ecosystem (BPS Kab. Kayong Utara, 2018).

\subsection{Remote Sensing Data and Analysis}

To obtain data on changes in forest cover, we using 12 images of Landsat series satellite. These are the images that were used for this article:

1. Landsat TM acquired on 12 September 1989 and 3 October 1989.

2. Landsat TM acquired on 21 July 1997, 22 August 1997 and 28 December 1997.

3. Landsat ETM+ acquired on 25 June 2002, 11 July 2002 and 28 August 2002

4. Landsat TM acquired on 7 July 2007.

5. Landsat TM acquired on 30 September 2011.

6. Landsat 8 (OLI) acquired on 7 July 2015 ,

7. Landsat 8 (OLI) acquired on 15 July 2018.

The images (path/row 121/61) have 30-meter resolution and are geometrically projected to the UTM zone 50S (WGS 1984 datum). The latest park border (decree number SK.733/Menhut-II/2014) was used to delineate the forest border.

The images were classified with visual interpretation and maximum likelihood classification methods (Hagner and Reese, 2007). For the land cover classes, we used modified classifications from Anderson et al. (1976). The images were classified into (1) Montane forest, (2) peat swamp forest, (3) lowland forest, (4) mangrove forest, (5) secondary lowland forest, (6) secondary montane forest, (7) secondary peat swamp forest, (8) second-growth lowland forest, (9) forest garden, (10) agriculture, (11) garden, (12) settlement, (13) degraded forest, and (14) scrub or open land. From these 14 classifications, five clusters were created for mapping: Intact forest (1-4), secondary forest (5-8), forest garden (8), agriculture and garden (10-12), degraded forest (13), and scrub or open land (14). The result was validated with a ground check and with a fine spatial resolution of SPOT 6 images. between 1992-2004. The data used was Landsat TM acquired at 1992, Landsat ETM+ acquired at 199, and SPOT 5 image acquired at 2004. Zamzani et al. (2009) only showed classification tables and didn't produce any maps. Tricahyono et al. (2016) also used Landsat images to analyze forest changes in the park. The data used was acquired in 2005 and 2012. They found that only $1,122.21 \mathrm{Ha}$ of the national park had been deforested. This research didn't explain the deforestation during the 1990s. The most recent research that explains agents and drivers of 
deforestation was conducted by Yoshikura et al. (2016). Yoshikura et al. (2016) performed a land cover analysis in 2013, but there were many missclassifications, where only some garden areas were classified as secondary forest because they had the same canopy as the forest. Although the cause of deforestation had was explained in the paper, the data was the limitated by one-time measurements of the forest. The latest research about forest monitoring was conducted by Fawzi et al. (2018), who measured annual deforestation rate in Gunung Palung National Park. This research had some limitations because it didn't explain the El Niño events of 2015 or the second-growth secondary forest. Some areas from the degraded forest regenerated into a secondary forest. The previous research didn't explain the impact of forest changes; rather, they only identfied the cause of deforestation. Two of the studies also failed to explain the process of ecosystem change in the park because of a lack of long-term monitoring.

Forest monitoring usually uses in situ data collection, but it can be expensive if it is done in a large conservation area and it will be much more difficult to collect data in remote areas. Using remote sensing techniques is the best option because it is time- and cost-effective and can capture long-term changes (Grecchi et al., 2017; Langner et al., 2012; Wang et al., 2010). Part of forest monitoring is assessing environmental impact from change in the forest.

The aim of this research is to monitor forest change in Gunung Palung National Park and to discuss its implication for the environment. In this article, we analyze forest change from 1989 to 2018 and discuss the environmental impact from the changes.

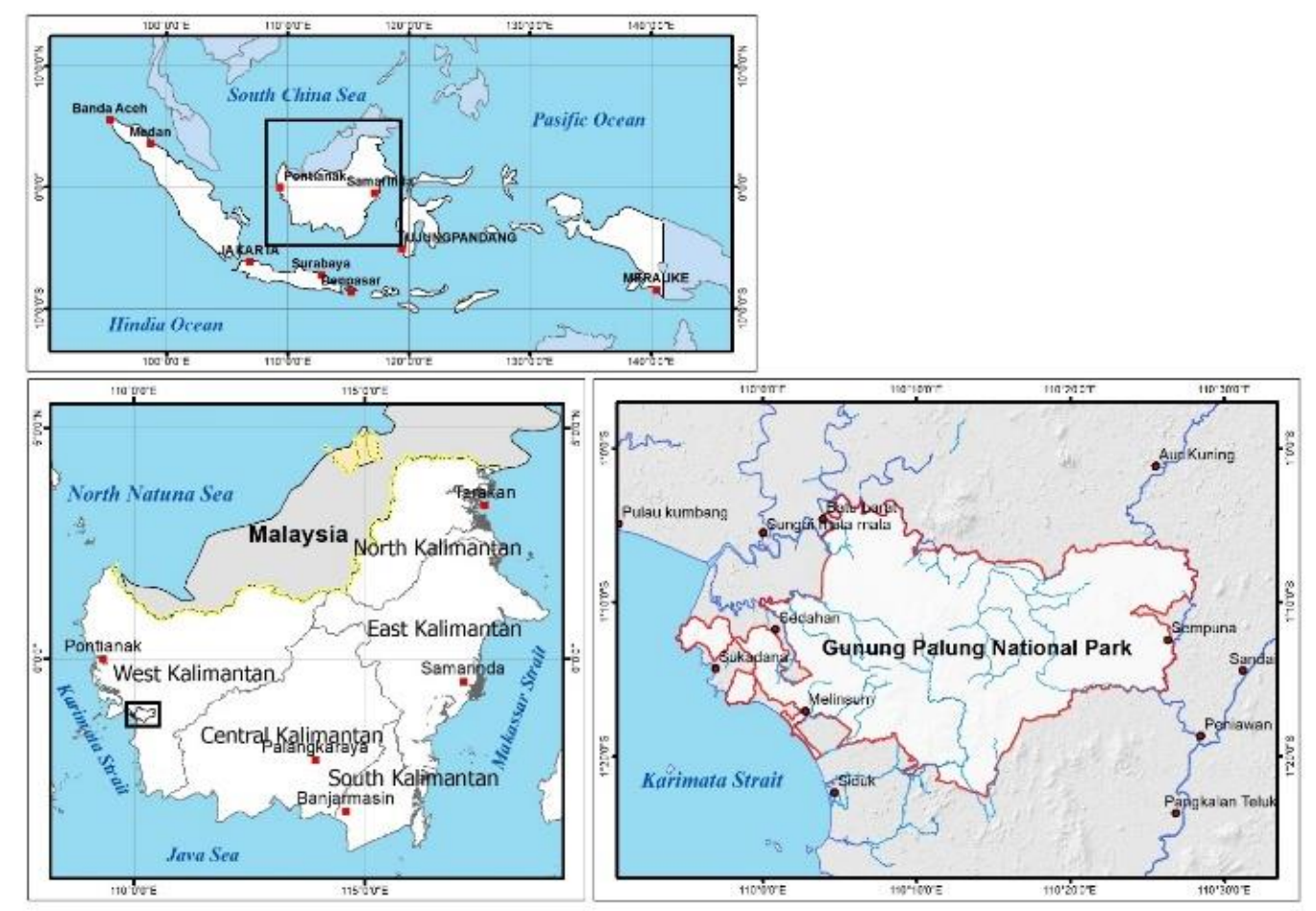

Figure 1. Study area in Gunung Palung National Park.

\subsection{Environmental Impact from Forest Change}

In this research, "environmental impact" is defined as a change in the forest, whether bad or good, resulting from any activity (Bai and Bai, 2014). In this article, the environmental indicators that will be discussed are forest cover change, biodiversity, human health, temperature, and other environmental indicator like major weather events such as floods and drought. Several indicators could not be measured quantitatively, a limitation of this study. This analysis was conducted through a literature review of research on Gunung Palung National Park.

To analyse the impact on human health, we used reports of Dengue and malaria cases from the
ASRI Clinic that serves patients from 35 sub-villages that directly border the park. The report was compared to a report from North Kayong Regency's health department from same year. Unstructured interviews were conducted with communities who lived around the park. These interviews obtained indepth information about environmental changes that were felt by the community.

\section{Result and Discussion}

\subsection{Forest Loss Measurement}

The accuracy of the maps from ground-truth data is $95,7 \%$ after ground validation. From table $\mathbf{1}$ and figure 2 , by 1989 , the park had already lost 
10,864 Ha or $10 \%$ of its forest. The old-growth forest remained at $90 \%$ or $97,148 \mathrm{Ha}$. This initial loss was caused by old agriculture and durian plantations inside the park. This agricultural activity near populated areas has existed for a long time, even before Gunung Palung became a national park (Salafsky, 1994).

In 1997, El Niño events caused a drought season which in turn caused a massive forest fire (Sloan et al., 2017). This event caused the park to lose nearly $30 \%$ of the old-growth forest measured in 1989. This report is similar to the results from Curran et al. (2004), which stated that the park lost 38\% of its forest. But this is different from Zamzani et al. (2009), which found that the park had lost 12,384 Ha from $1992-2004$, or only $12 \%$ of 1989's old-growth forest. The result is different because they used a three-point measurement, in 1992, 1999, and 2004, where the degraded forest in 1997 had already regenerated in 1999 and was classified as forest that had not changed since 1992. The loss in this period was caused by individual loggers and timber companies who expanded their operations illegally into the park to meet growing demands for timber. In this timeline, the national park had a high loss of forest because there was no intervention to prevent forest loss.

Since 2002, 95\% of degraded forest has been regenerating naturally into secondary forest or second-growth forest. This forest loss has been decreasing because there was a transition in our policy related to forest management. The latest deforestation in 2015 was caused by the El Niño events of 2015-16, and it caused severe forest fires (Jan Null, 2018; Sloan et al., 2017). This period was not explained by Fawzi et al. (2018). Forest fires were the main event that caused the loss of $1.1 \%$ of the park's forest. The park lost more than $521 \mathrm{Ha}$ of peat swamp forest and $230 \mathrm{Ha}$ of lowland forest. This wildfire turned $693 \mathrm{Ha}$ forest into scrub or open area.

Since 2015, following the El Niño events, no deforestation was detected from 30-meter resolution of Landsat satellite. But the park still has 5,098,8 Ha (5\%) of open area that will always be occupied by Japanese blood grass (Imperata cylindrica (L.) P.Beauv.) or ferns (Pteridium aquilinum) if restoration attempts are not made. ASRI conducted several reforestation projects in the park and contributed to the increase of secondary forest during the period 2015 - 2018 (Pohnan et al., 2015).

This result is a positive trend (Figure 3 ) which must be continued for the sake of forest conservation. No deforestation is a result of combined conservation efforts by the national park staff, NGOs, government, and local communities. Although the results are trending towards positive change, problems remain, because $67 \%$ of local people have the perception that protecting the park is not important (Sudrajat et al., 2018). Increasing local people's commitment and perception is important to reduce deforestation (Garrett et al., 2019).

Table 1. Forest cover change in Gunung Palung National Park from 1989 - 2018

\begin{tabular}{|c|c|c|c|c|c|c|c|c|}
\hline No & Ecosystem & 1989 & 1997 & 2002 & 2007 & 2011 & 2015 & 2018 \\
\hline 1 & Montane forest & $22,126.8$ & $22,126.8$ & $22,126.8$ & $22,126.8$ & $22,126.8$ & $22,126.8$ & $22,126.8$ \\
\hline 2 & Peat swamp forest & $20,862.7$ & $17,755.7$ & $17,751.9$ & $17,604.2$ & $17,486.0$ & $17,480.4$ & $16,959.3$ \\
\hline 3 & Lowland forest & $53,762.6$ & $32,405.5$ & $31,974.3$ & $31,173.3$ & $30,706.0$ & $30,654.8$ & $30,424.6$ \\
\hline 4 & Mangrove forest & 395.6 & 395.6 & 395.6 & 382.7 & 382.7 & 375.5 & 339.9 \\
\hline 5 & Secondary lowland forest & 0.0 & 279.1 & $4,319.9$ & $4,563.3$ & $5,147.0$ & $5,570.0$ & $5,650.5$ \\
\hline 6 & Secondary montane forest & 0.0 & 0.0 & 7.4 & 7.4 & 7.4 & 7.4 & 7.4 \\
\hline 7 & Secondary peat swamp forest & 0.0 & $2,346.1$ & $2,801.0$ & $3,354.9$ & $3,481.5$ & $3,510.9$ & $3,470.5$ \\
\hline 8 & Second-growth lowland forest & 0.0 & 55.6 & $15,182.8$ & $15,768.4$ & $15,767.9$ & $15,918.4$ & $15,921.2$ \\
\hline 9 & Forest garden & $2,853.2$ & $2,853.1$ & $3,755.4$ & $3,761.5$ & $3,818.4$ & $3,818.7$ & $3,781.0$ \\
\hline 10 & Agriculture & 43.8 & 43.8 & 92.5 & 105.4 & 379.6 & 391.6 & 409.9 \\
\hline 11 & Garden & $4,508.3$ & $4,281.4$ & $3,487.9$ & $3,298.1$ & $3,698.9$ & $3,721.6$ & $3,791.6$ \\
\hline 12 & Settlement & 0.0 & 0.0 & 0.0 & 31.0 & 31.0 & 31.0 & 31.0 \\
\hline 13 & Degraded forest & 443.4 & $16,061.2$ & 814.7 & 0.0 & 0.0 & 0.0 & 0.0 \\
\hline \multirow[t]{2}{*}{14} & Scrub or open land & $3,016.3$ & $9,408.6$ & $5,302.4$ & $5,835.5$ & $4,979.4$ & $4,405.6$ & $5,098.8$ \\
\hline & Total & $108,012.6$ & $108,012.6$ & $108,012.6$ & $108,012.6$ & $108,012.6$ & $108,012.6$ & $108,012.6$ \\
\hline
\end{tabular}



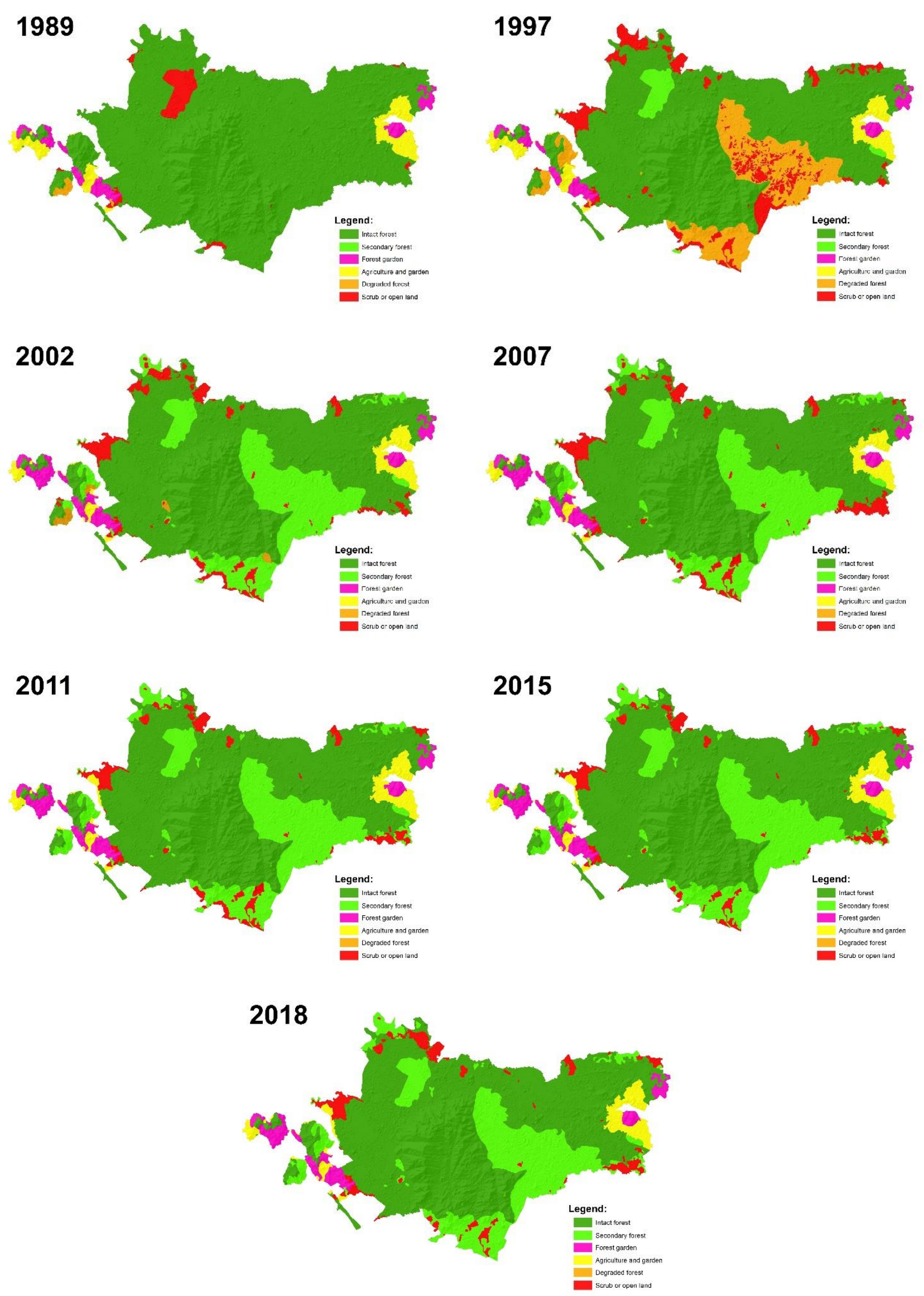

Figure 2. Trend of forest change in Gunung Palung National Park. 


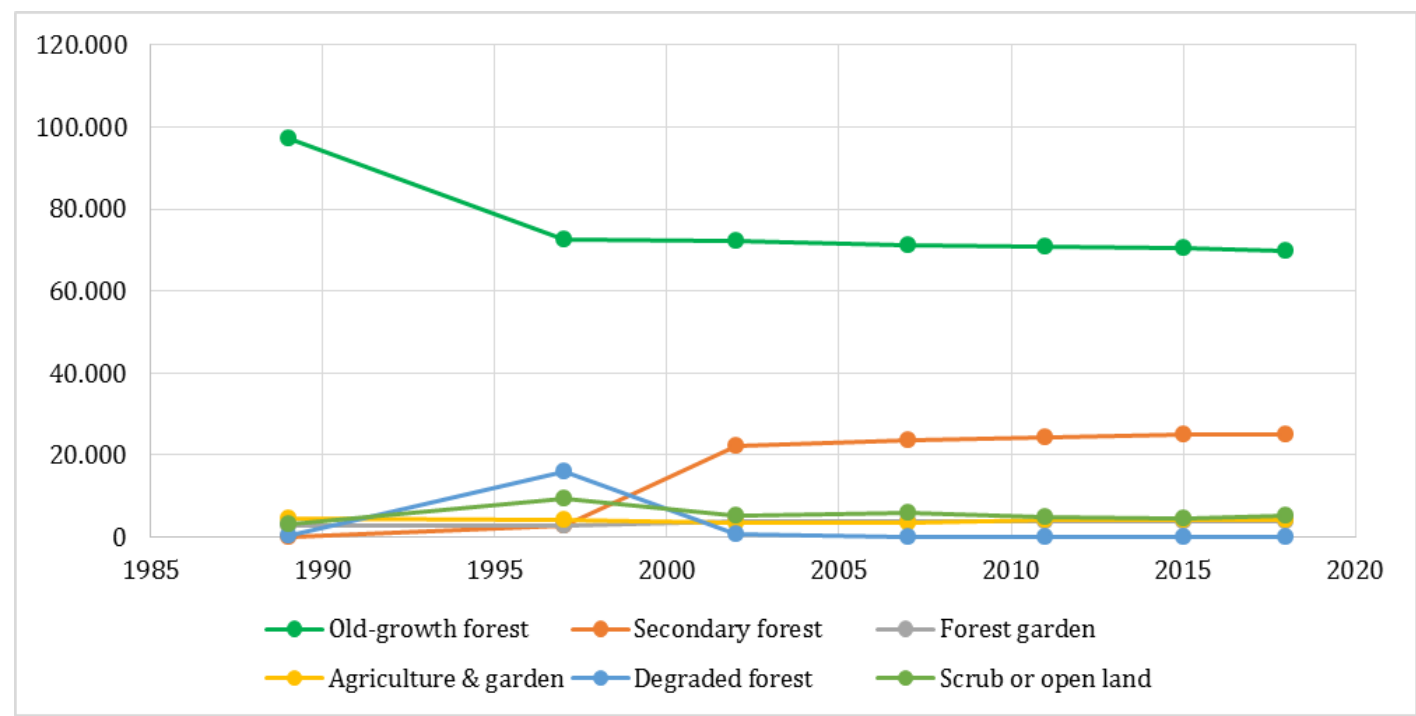

Figure 3. Trend of forest change in Gunung Palung National Park.

\subsection{Forest Change and Its Implication to Environmental}

The change of forest cover in Gunung Palung National Park impacted the ecosystem. Figure $\mathbf{3}$ shows how old-growth forest dropped in 1997 2002 and hasn't changed much since then. The oldgrowth loss was offset by increasing secondgrowth/secondary forest, contribute to $26 \%$ of remaining forest in the park in 2018. Although the forest is growing again, the secondary forest has a less complex composition of plants, trees, and fauna compare to the old-growth forest. Sixteen years of secondary forest growth $(2002-2018)$ is a relatively short period to support ecosystem function compared to old-growth forest. The 16-18 year old secondary forest has lower floristic composition compared to the old-growth forest (Guariguata et al., 1997). The park also has $5 \%$ of its area which is still open because it failed to naturally regenerate. The open area/grassland (I. cylindrica and P. aquilinum) negatively impacts the forest ecosystem because it can initiate wildfires (Kiyono and Hastaniah, 2000).

The change of forest to secondary forest affects biological diversity. Biological diversity or biodiversity is the variety of life forms in an ecosystem and exists within three scales: Genetic, species, and ecosystem. Different wildlife and vegetation have different responses to their habits changing into secondary forest. The forest change in Gunung Palung National Park can alter dipterocarp and ironwood fruiting, changing ecology and reproductive cycles for endemic animals (Phillips, 1997), and livelihood activities can be modified due to drought or floods (van Dijk et al., 2009). This also drives invasive species Bellucia pentamera Naudin to occupy the gap canopy in the park (Dillis et al., 2017), or causes non-native species to become abundant and make native species more vulnerable to extinction (Zieritz et al., 2018). Deforestation also leads to the reduction of macro-invertebrate abundance and loss of biodiversity (Al-Shami et al., 2017). Gunung Palung National Park has become an "island" or isolated environment that has transformed into palm oil plantations. This place is the only habitat for orangutans in the region. We are very about biodiversity loss that can affect orangutan habitats. Changes during fruiting season have caused forest fruit to be less abundant, leading orangutans to expand their search for food. Forest structure is also important for maintaining orangutan densities and other frugivore structure in Gunung Palung National Park (Marshall et al., 2014).The result of these changes is that orangutans will come to populated areas to find food, creating conflict with the people from the communities surrounding the park. If deforestation and degradation still happen in the future, orangutans will lose their food and habitat.

Deforestation and changes in biodiversity can also affect human health, leading to the transmission of pathogens or the emergence of diseases like malaria and parasitic diseases (Hammen and Settele, 2011; Patz et al., 2000). Deforestation will cause humans to live at the edge of the forest (as shown in table 1 where the settlements occupied the old forest). This condition will increase human's chance to have contact with pathogenic carriers such as mosquitoes. Dengue and malaria are two diseases that are linked to deforestation or forest changes (Franklinos et al., 2019). If forest decreases or ecosystems get degraded, the prevalence of these diseases will eventually increase.

Figure 4 shows that Dengue has a higher incidence rate than malaria. In 2013, we had 43 cases of Dengue, which decreased to 15 cases in 2018 (ASRI report 2018). In 2015 - 2016 we had the lowest cases of Dengue because El Niño caused a drought and large forest fire that reduced the mosquito population. This number mirrors the Dengue cases from North Kayong Regency, a total of 9 and 10 in 
2015 and 2016, respectively (Dinas Kesehatan \& KB, 2017). In 2017, Dengue cases increased because of La Niña events that caused major flooding around the region (DiNezio et al., 2017). Flooding causes an increase in mosquito populations and eventually increases the incidence of Dengue.

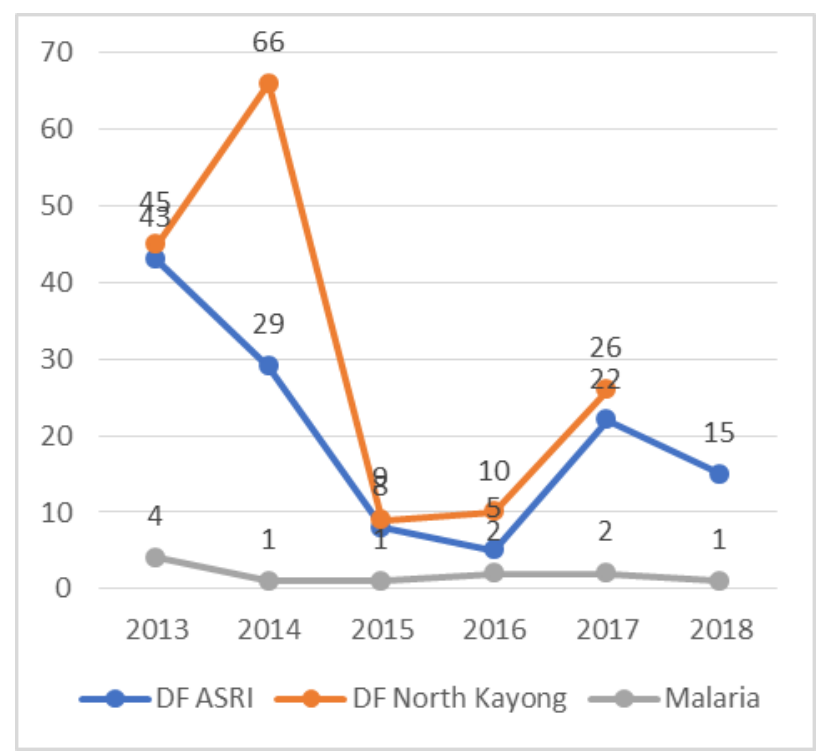

Figure 4. Total cases of malaria and Dengue at ASRI's Clinic (DF ASRI and Malaria) and total cases in North Kayong Regency, West Kalimantan (DF North Kayong).

The changes in the forest also increase the surface temperature. As measured by remote sensing techniques, old growth forests have lower average temperatures compared to other categories, $30.7^{\circ} \mathrm{C}$. Surprisingly, the average surface temperature of old growth forest and secondary forest are the same. The average surface temperature in populated areas is $34.2^{\circ} \mathrm{C}$, which is $3.5^{\circ} \mathrm{C}$ difference between old growth forest. The average temperatures of the forest garden and palm oil plantations are $33.5^{\circ} \mathrm{C}-33.9^{\circ} \mathrm{C}$, respectively. Thus, the changes resulting from deforestation can lead to a temperature increase of up to $4.4 \pm 0.07 \mathrm{~K} \quad\left(=4.4 \pm 0.07^{\circ} \mathrm{C}\right) \quad$ (Schultz et al., 2017).

When forests change into secondary forests or are used for other types of use, surface water retention changes, which in turn affects responses to extreme events like floods and drought. This will cause a decrease of water availability especially in dry season. Later on, this condition will cause salt water intrusion into the river, especially at the northern part of the park. The shortage will be worse alongside areas experiencing population growth. People in Sukadana, the nearest city to the park, must spend 120,000 rupiah to buy 2,000 liters of water (Cahyono, 2019). Usually people obtain water for free. The water depletion can also impact crop failure because there is reduced water for irrigation. Conservation efforts that work to protect and restore remaining forests can increase the water retention function of the forest (Reinhardt-Imjela et al., 2017).
The change of forest composition after logging will cause flooding and an increasing number of pests. This happens due to an increase in surface runoff as the result of deforestation and increase in precipitation (Takahashi et al., 2017). Forest loss in a national park and its surrounding area contributed to flooding that occurred recently in Sukadana (Al Birra, 2017).

In the future, we must think about reforestation because reforestation has a big impact on improving biodiversity and on carbon sequestration (Helms et al., 2018; Locatelli et al., 2015). Monitoring using remote sensing data and open source data will be important for forest management. This data will help support efforts to develop a land-use system that is environmentally and economically sustainable. Knowing the process of how and why these change over time is important, especially when studying the long-term gain or loss of forests (e.g. reforestation).

\section{Conclusion}

Forest monitoring is an important tool for forest conservation, especially for monitoring forest changes. At the beginning of monitoring, the park had already lost 10,864 Ha or $10 \%$ of its forest, and $90 \%$ or $97,148 \mathrm{Ha}$ of old-growth forest remained. This initial loss was caused by old agricultural activities and durian plantations inside the park. The El Niño events of 1997 made the park lost nearly $30 \%$ of its forest and another event in 2015 made the park lose $1.1 \%$ of the forest respectively. Alongside droughts and wildfire, the forest loss was caused by individual loggers and timber companies who expanded their operations illegally into the park to meet the growing demand for timber. The implication for the environment is that the change of $26 \%$ of the park to secondary forest affected biological diversity. The change also drove invasive species Bellucia pentamera Naudin to occupy the gap canopy in the park and 5,098,8 $\mathrm{Ha}$ (5\%) of open area that will always be occupied by Japanese blood grass (Imperata cylindrica (L.) P.Beauv.) or fern (Pteridium aquilinum). The less dense secondary forest also creates less water retention and will cause a decrease of water availability, especially in the dry season. In the future, we must think about reforestation because reforestation also has a positive impact on improving biodiversity.

\section{REFERENCE}

Al-Shami, S.A., Rawi, C.S.M., Ahmad, A.H., Madrus, M.R., Hamid, S.A., Ghani, W.M.H.W.A., Awwad Al-Harbi, N., AlMutairi, K.A., 2017. Biodiversity patterns of aquatic macroinvertebrates in tropical forests streams as a response to logging activities and deforestation. Acta Ecologica Sinica, Vol. 37, 332-339.

Al Birra, F., 2017. Sukadana Dikepung Banjir, Katanya Terparah Dekade Ini [WWW Document]. URL 
https://www.jawapos.com/jpg-

today/04/06/2017/sukadana-dikepung-banjir-

katanya-terparah-dekade-ini/ (accessed 8.8.19).

Ancrenaz, M., Gumal, M., Marshall, A.J., Meijaard, E., Wich, S.A., Husson, S., 2016. Pongo pygmaeus (errata version published in 2018). The IUCN Red List of Threatened Species 2016: e.T17975A123809220. [WWW Document]. URL https://www.iucnredlist.org/species/17975/12380 9220 (accessed 8.1.19).

Anderson, J.R., Hardy, E.E., Roach, J.T., Witmer, R.E., 1976. A Land Use and Land Cover Classification System for Use with Remote Sensor Data. United States Geological Survey Professional Paper, Vol. 964.

Baccini, A., Goetz, S.J., Walker, W.S., Laporte, N.T., Sun, M., Sulla-Menashe, D., Hackler, J., Beck, P.S.A., Dubayah, R., Friedl, M.A., Samanta, S., Houghton, R.A., 2012. Estimated carbon dioxide emissions from tropical deforestation improved by carbon-density maps. Nature Climate Change, Vol. 2, 182-185.

Bai, Y., Bai, Q., 2014. Environmental Impact Assessment. In: Subsea Pipeline Integrity and Risk Management. Gulf Professional Publishing, pp. 363-376.

Barlow, J., Lennox, G.D., Ferreira, J., Berenguer, E., Lees, A.C., Nally, R. Mac, Thomson, J.R., Ferraz, S.F. de B., Louzada, J., Oliveira, V.H.F., Parry, L., Ribeiro de Castro Solar, R., Vieira, I.C.G., Aragão, L.E.O.C., Begotti, R.A., Braga, R.F., Cardoso, T.M., Jr, R.C. de O., Souza Jr, C.M., Moura, N.G., Nunes, S.S., Siqueira, J.V., Pardini, R., Silveira, J.M., Vaz-de-Mello, F.Z., Veiga, R.C.S., Venturieri, A., Gardner, T.A., 2016. Anthropogenic disturbance in tropical forests can double biodiversity loss from deforestation. Nature, Vol. 535, 144-147.

BirdLife International, 2018. Buceros rhinoceros. The IUCN Red List of Threatened Species 2018: e.T22682450A132376232. [WWW Document]. URL https://www.iucnredlist.org/species/22682450/13 2376232 (accessed 8.2.19).

BPS Kab. Kayong Utara, 2018. Statistik Daerah Kabupaten Kayong Utara 2018. Badan Pusat Statistik Kabupaten Kayong Utara, Sukadana.

Cahyono, A., 2019. Warga Sukadana Kesulitan Air Bersih, Terpaksa Gunakan Uang Lauk untuk Beli Air - Tribun Pontianak [WWW Document]. URL https://pontianak.tribunnews.com/2019/08/02/wa rga-sukadana-kesulitan-air-bersih-terpaksagunakan-uang-lauk-untuk-beli-air (accessed 8.22.19).

Curran, L.M., Trigg, S.N., Mcdonald, a K., Astiani, D., 2004. Lowland Forest Loss in Protected Areas. Terra, Vol. 303, 1000-1003.

Curtis, P.G., Slay, C.M., Harris, N.L., Tyukavina, A., Hansen, M.C., 2018. Classifying drivers of global forest loss. Science (New York, N.Y.), Vol. 361, 1108-1111.

Dillis, C., Marshall, A.J., Rejmánek, M., 2017. Change in disturbance regime facilitates invasion by Bellucia pentamera Naudin (Melastomataceae) at Gunung Palung National Park, Indonesia. Biological Invasions, Vol. 19, 1329-1337.

Dinas Kesehatan \& KB, 2017. Profil Kesehatan Dan Keluarga Berencana Tahun 2017 Kabupaten Kayong Utara. Sukadana.

DiNezio, P.N., Deser, C., Karspeck, A., Yeager, S., Okumura, Y., Danabasoglu, G., Rosenbloom, N., Caron, J., Meehl, G.A., 2017. A 2 Year Forecast for a $60-80 \%$ Chance of La Niña in 2017-2018. Geophysical Research Letters,
Vol. 44, 11,624-11,635.

Fawzi, N.I., Husna, V.N., Helms, J.A., 2018. Measuring deforestation using remote sensing and its implication for conservation in Gunung Palung National Park, West Kalimantan, Indonesia. In: IOP Conference Series: Earth and Environmental Science.

Franklinos, L.H. V, Jones, K.E., Redding, D.W., Abubakar, I., 2019. The effect of global change on mosquito-borne disease. The Lancet Infectious Diseases,

Garrett, R.D., Levy, S., Carlson, K.M., Gardner, T.A., Godar, J., Clapp, J., Dauvergne, P., Heilmayr, R., le Polain de Waroux, Y., Ayre, B., Barr, R., Døvre, B., Gibbs, H.K., Hall, S., Lake, S., Milder, J.C., Rausch, L.L., Rivero, R., Rueda, X., Sarsfield, R., Soares-Filho, B., Villoria, N., 2019. Criteria for effective zero-deforestation commitments. Global Environmental Change, Vol. 54, 135-147.

Gaveau, D.L.A., Locatelli, B., Salim, M.A., Yaen, H., Pacheco, P., Sheil, D., 2019. Rise and fall of forest loss and industrial plantations in Borneo (2000-2017). Conservation Letters, Vol. 12, e12622.

Gaveau, D.L.A., Sheil, D., Husnayaen, Salim, M.A., Arjasakusuma, S., Ancrenaz, M., Pacheco, P., Meijaard, E., 2016. Rapid conversions and avoided deforestation: Examining four decades of industrial plantation expansion in Borneo. Scientific Reports, Vol. 6 .

Giam, X., 2017. Global biodiversity loss from tropical deforestation. Proceedings of the National Academy of Sciences of the United States of America, Vol. 114, 5775-5777.

Grecchi, R.C., Beuchle, R., Edemir, Y., Aragão, L.E.O.C., Arai, E., Simonetti, D., Achard, F., 2017. An integrated remote sensing and GIS approach for monitoring areas affected by selective logging: A case study in northern Mato Grosso, Brazilian Amazon. International Journal of Applied Earth Observation and Geoinformation, Vol. 61, 70-80.

Guariguata, M.R., Chazdon, R.L., Denslow, J.S., Dupuy, J.M., Anderson, L., 1997. Structure and floristics of secondary and old-growth forest stands in lowland Costa Rica. Plant Ecology, Vol. 132, 107-120.

Hagner, O., Reese, H., 2007. A method for calibrated maximum likelihood classification of forest types. Remote Sensing of Environment, Vol. 110, 438-444.

Hammen, V.C., Settele, J., 2011. Biodiversity and the Loss of Biodiversity Affecting Human Health. In: Encyclopedia of Environmental Health. Elsevier, pp. 353-362.

Hearn, A., Ross, J., Brodie, J., Cheyne, S., Haidir, I.A., Loken, B., Mathai, J., Wilting, A., McCarthy, J., 2015. Neofelis diardi (errata version published in 2016). The IUCN Red List of Threatened Species 2015: e.T136603A97212874. [WWW Document]. URL https://www.iucnredlist.org/species/136603/9721 2874 (accessed 8.2.19).

Helms, J.A., Woerner, C.R., Fawzi, N.I., MacDonald, A., Juliansyah, Pohnan, E., Webb, K., 2018. Rapid Response of Bird Communities to Small-Scale Reforestation in Indonesian Borneo. Tropical Conservation Science, Vol. 11, 194008291876946.

Hiller, M.A., Jarvis, B.C., Lisa, H., Paulson, L.J., Pollard, E.H.B., Stanley, S.A., 2004. Recent trends in illegal logging and a brief discussion of their causes: a case study from Gunung Palung National Park, Indonesia. Journal of Sustainable Forestry, Vol. 19, 181-212.

Jan Null, 2018. El Niño and La Niña Years and Intensities 
Based on Oceanic Niño Index (ONI) [WWW Document]. Golden Gate Weather Services,. URL http://ggweather.com/enso/oni.htm

Johnson, A.E., Knott, C.D., Pamungkas, B., Pasaribu, M., Marshall, A.J., 2005. A survey of the orangutan (Pongo pygmaeus wurmbii) population in and around Gunung Palung National Park, West Kalimantan, Indonesia based on nest counts. Biological Conservation, Vol. 121, 495-507.

Kiyono, Y., Hastaniah, 2000. The Role of Slash-and-Burn Agriculture in Transforming Dipterocarp Forest into Imperata Grassland. pp. 199-208.

Langner, A., Samejima, H., Ong, R.C., Titin, J., Kitayama, K., 2012. Integration of carbon conservation into sustainable forest management using high resolution satellite imagery: A case study in Sabah, Malaysian Borneo. International Journal of Applied Earth Observation and Geoinformation, Vol. 18, 305-312.

Locatelli, B., Catterall, C.P., Imbach, P., Kumar, C., Lasco, R., Marín-Spiotta, E., Mercer, B., Powers, J.S., Schwartz, N., Uriarte, M., 2015. Tropical reforestation and climate change: beyond carbon. Restoration Ecology, Vol. 23, 337-343.

Marshall, A.J., Beaudrot, L., Wittmer, H.U., 2014. Responses of Primates and Other Frugivorous Vertebrates to Plant Resource Variability over Space and Time at Gunung Palung National Park. International Journal of Primatology, Vol. 35, 1178-1201.

Meijaard, E., Nijman, V., Supriatna, J., 2008. Nasalis larvatus. The IUCN Red List of Threatened Species 2008: e.T14352A4434312.

Patz, J.A., Graczyk, T.K., Geller, N., Vittor, A.Y., 2000. Effects of environmental change on emerging parasitic diseases. International Journal for Parasitology, Vol. 30, 1395-1405.

Phillips, O.L., 1997. The changing ecology of tropical forests. Biodiversity and Conservation, Vol. 6, 291-311.

Pohnan, E., Ompusunggu, H., Webb, C., 2015. Does tree planting change minds? Assessing the use of community participation in reforestation to address illegal logging in West Kalimantan. Tropical Conservation Science, Vol. 8, 45-57.

Rasmussen, L.V., Jepsen, M.R., 2018. Monitoring systems to improve forest conditions. Current Opinion in Environmental Sustainability, Vol. 32, 29-37.

Reinhardt-Imjela, C., Imjela, R., Bölscher, J., Schulte, A., 2017. The impact of late medieval deforestation and 20th century forest decline on extreme flood magnitudes in the Ore Mountains (Southeastern Germany). Quaternary International,.

Rosa, I.M.D., Smith, M.J., Wearn, O.R., Purves, D., Ewers, R.M., 2016. The Environmental Legacy of Modern Tropical Deforestation. Current Biology, Vol. 26, 2161-2166.

Salafsky, N., 1994. Forest gardens in the Gunung Palung region of West Kalimanta, Indonesia. Agroforestry Systems, Vol. 28, 237-268.

Schultz, N.M., Lawrence, P.J., Lee, X., 2017. Global satellite data highlights the diurnal asymmetry of the surface temperature response to deforestation. Journal of Geophysical Research: Biogeosciences, Vol. 122, 903917.

Scotson, L., Fredriksson, G., Augeri, D., Cheah, C., Ngoprasert, D., Wai-Ming, W., 2017. Helarctos malayanus (errata version published in 2018). The
IUCN Red List of Threatened Species 2017: e.T9760A123798233. [WWW Document]. URL https://www.iucnredlist.org/species/9760/123798 233 (accessed 8.2.19).

Sloan, S., Locatelli, B., Wooster, M.J., Gaveau, D.L.A., 2017. Fire activity in Borneo driven by industrial land conversion and drought during El Niño periods, 1982-2010. Global Environmental Change, Vol. 47, 95-109.

Sudrajat, J., Sawerah, S., Permatasari, N., Suharyani, A., Karmoni, A., Anshari, G.Z., Wardhana, D., Rossanda, D., 2018. People's views towards Gunung Palung National Park, West Kalimantan, Indonesia. Biodiversitas, Vol. 19, 1138-1146.

Tacconi, L., Rodrigues, R.J., Maryudi, A., 2019. Law enforcement and deforestation: Lessons for Indonesia from Brazil. Forest Policy and Economics, 101943.

Takahashi, A., Kumagai, T., Kanamori, H., Fujinami, H., Hiyama, T., Hara, M., 2017. Impact of Tropical Deforestation and Forest Degradation on Precipitation over Borneo Island. Journal of Hydrometeorology, JHM-D-17-0008.1.

Tricahyono, K., Riyono, J.N., Latifah, S., 2016. Land Cover Change Analysis By Using Landsat ETM7+ Image in Gunung Palung National Park Residing in The District of North Kayong West Kalimantan Province. Jurnal Hutan Lestari, Vol. 4, 401-408.

Tsujino, R., Yumoto, T., Kitamura, S., Djamaluddin, I., Darnaedi, D., 2016. History of forest loss and degradation in Indonesia. Land Use Policy, Vol. 57, 335-347.

van Dijk, A.I.J.M., van Noordwijk, M., Calder, I.R., Bruijnzeel, S.L.A., Schellekens, J.A.A.P., Chappell, N.A., 2009. Forest-flood relation still tenuous - Comment on 'Global evidence that deforestation amplifies flood risk and severity in the developing world'by C. J. A. Bradshaw, N.S. Sodi, K. S.-H. Peh and B.W. Brook. Global Change Biology, Vol. 15, 110-115.

Wang, K., Franklin, S.E., Guo, X., Cattet, M., 2010. Remote sensing of ecology, biodiversity and conservation: a review from the perspective of remote sensing specialists. Sensors (Basel, Switzerland), Vol. 10, 9647-67.

Yoshikura, T., Amano, M., Chikaraishi, H., Supriyanto, B., Wardhana, D., 2016. Evaluation of Appropriate Identification of Deforestation Agents and Drivers for Designing REDD+ Readiness Activities through an Examination of the Area around Gunung Palung National Park, Indonesia. Open Journal of Forestry, Vol. 06, 106-122.

Zamzani, F., Onda, N., Yoshino, K., Masuda, M., 2009. Deforestation and agricultural expansion processes in Gunung Palung National Park, West Kalimantan, Indonesia. Jurnal Manajemen Hutan Tropika, Vol. 15, 24-31.

Zieritz, A., Bogan, A.E., Rahim, K.A.A., Sousa, R., Jainih, L., Harun, S., Razak, N.F.A., Gallardo, B., McGowan, S., Hassan, R., Lopes-Lima, M., 2018. Changes and drivers of freshwater mussel diversity and distribution in northern Borneo. Biological Conservation, Vol. 219, 126-137. 